\title{
Burnout syndrome and Brazilian civil aviation: a short essay on the focus on prevention
}

\author{
Castro $\mathrm{M}^{\mathrm{a}}$, Araujo $\mathrm{L}^{\mathrm{b}}$ \\ ${ }^{a}$ University of Gama Filho, Treze de Maio St, 681, 01327-000, São Paulo, Brazil. \\ ${ }^{\mathrm{b}}$ Health Environmental Department, School of Public Health, University of São Paulo,.
}

\begin{abstract}
Introduction: At the same time that there are increased demands we have become more sedentary, increasing risk factors for new diseases. All this reflects on our quality of life with special emphasis upon a particular syndrome called Burnout. Aviation is no exception and packed into its processes each day more expeditious, promotes a perfect environment for the development and spread of the syndrome. Aim: To evaluate the quality of life, organizational climate, and the level of physical activity among employees of a Brazilian airline. Methods: A cross-sectional design was conducted with 8 subjects. Results: Total score on the WHOQOL quality of life questionnaire was 64.7 (SD 10.8), and the environmental field showed the lowest score. Nevertheless, the sedentary risk factor was performed in $25 \%$ of the sample. About the organizational climate, it can be seen that $6.12 \%$ of the sample was framed in "Professional Exhaustive", $29.60 \%$ in the condition of "Warning", and $64.37 \%$ in the condition of "Professional Efficiency". Conclusion: the study found a low quality of life, especially in the environmental category, sedentary people and a large proportion of employees in this Brazilian airline with negative scores on the Organizational Climate.
\end{abstract}

Keywords: Quality of Life, Organizational Climate, Environmental Work

\section{Introduction}

The theme of Occupational Health has mobilized researchers and organizations concerned with issues related to the work conditions and organization in its interference in the process health-illness.

To Dejours ${ }^{3}$, work permits growth, transformation, recognition and personal and professional independence. However, promotes problems like dissatisfaction, disaffection, apathy and irritation, i.e. there is no work without suffering. For this, a positive productivity is resulted of healthy and skilled. However, due to pressures imposed on the individual by the organization, it leads to pathologies, discontent and desmotivation ${ }^{7}$.

At the same time that there are increased demands we have become more sedentary and dependent on technology, generating or increasing risk factors for new diseases. All this reflects on our quality of life with special emphasis upon a particular syndrome called Burnout. This syndrome is a mental disorder ${ }^{*}$ and depressive character associated with the intense physical and mental exhaustion, and has causal link with work ${ }^{1}$. Aviation is no exception and packed into its processes each day more expeditious, promotes a perfect environment for the development and spread of the syndrome.

The current study aims to evaluate the quality of life, organizational climate, and the level of physical activity among employees of a Brazilian airline.

\section{Methods}

2.1. Study design

\footnotetext{
* Corresponding author: leanaaraujo@yahoo.com.br, Dr.Arnaldo Av, 715 CEP 01246-904, São Paulo, Brazil
} 
This study adopted a cross-sectional design. Data collection included application of four questionnaires covering sociodemographic, lifestyle, quality of life, physical activity and organizational climate.

\subsection{Study population}

The study population comprised eight employees, which are representative of all employees of the three shift work on a national airline based in São Paulo capital, Brazil and that works in an Operations Centre at an airport in the city of Rio de Janeiro, Brazil.

The workers studied had mean collaboration of 49 months $(\mathrm{SD}=20.6)$, the majority were female $(75 \%)$, with mean aged 28.5 years $(\mathrm{SD}=5)$, half the population was married with an average kids of 0,4 $(\mathrm{DP}=0,5)$.

They worked 36 hours per week, with a mean of 5,5 hours $(\mathrm{SD}=2,7)$ leisure per week. $25 \%$ had academic education with high school, and $62,5 \%$ had graduation with the last $12,5 \%$ with post graduation course.

\subsection{Data collection}

Data collection was conducted between March and May 2010, using questionnaire self-responsive by employees and administered before the work shift.

\subsection{Variables}

-Sociodemographic and lifestyle: it was collected data on age, sex, marital status, number of children, time in job, weekly leisure time, academic education, job satisfaction, working hours per day.

-Quality of life: the questionnaire WHOQOLBREF, Brazilian validation ${ }^{4}$, consists of 26 questions divided in four areas covering psychological, social, environmental and a total of the quality of life with Likert scale. The score ranges from 50 to 100 , being that the closer to 100 , the better the quality of life of the individual.

-Physical activity: the International Physical Activity Questionnaire - IPAQ ${ }^{6}$ was also used in its short version that collects data about walking, moderate-intensity physical activities, vigorous and sedentary behavior.

-Organizational climate: to assess this item, eight questions about the behaviors, beliefs and feelings about the individual experience as a professional civil aviation were adapted for the proposed research with quantitative values from 1 to 3 , considering, "professional exhaustion" occurs when more than three episodes per weeks occurs, the "condition of attention" when it occurs in up to three episodes per week and "professional efficiency" when the response is null, in that order. Following the questions:

1- I feel emotionally drained by my work.

2- I question the meaning and importance of my work.

3- I feel exhausted at the end of a shift.

4- I feel tired when I get up to face another day of work.

5- Study and work are, for me, a great effort.

6- I have being less interested in studies since I started this work.

7- I have being more stressed out about my studies.

8- I have being consumed by my work.

\subsection{Data analysis}

Data of the questionnaires were first analyzed for statistical distribution. The responses of employees to the questionnaires were analyzed using descriptive statistics with mean and standard deviation (SD).

\section{Results}

Based on the dichotomous satisfaction question, $87,5 \%$ answered yes, i.e. they are dissatisfied with the work.

It was observed total score on the quality of life questionnaire WHOQOL of 64.7 (SD 10.8), and the environmental field showed the lowest score, what reflected negatively on the Organizational Climate in relation to academic progress.

Table 1

Results of the of the WHOQOL-BREF categories descriptive analysis

\begin{tabular}{|l|r|}
\hline CATEGORIES & \multicolumn{1}{|c|}{ Mean \pm SD } \\
\hline Physical & $66,0 \pm 11,2$ \\
\hline Psychological & $70,8 \pm 9,2$ \\
\hline Social & $78,1 \pm 24,8$ \\
\hline Environmental & $54,3 \pm 16,2$ \\
\hline Total & $64,7 \pm 10,8$ \\
\hline
\end{tabular}

Among the sample was found $75 \%$ engaged in some kind of physical activity, ranging from irregularly active to very active, and $25 \%$ of the sample fitted to sedentary category (inactive). 
Nevertheless, the lifestyle risk factor was performed in $25 \%$ of the sample, but not relevant for the indication of symptoms of Burnout.

In relation to the total score on the Organizational Climate can be seen that $6.12 \%$ of the sample was framed in that "Professional Exhaustion", $29.60 \%$ in the condition of " Warning", and $64.37 \%$ in the condition of "Professional Efficiency".

Table 2

Results of Organizational Climate issues

\begin{tabular}{|c|c|c|c|}
\hline $\begin{array}{c}\text { Question } \\
\mathrm{N}^{\circ}\end{array}$ & $\begin{array}{c}1 \\
\text { Professional } \\
\text { Exhaustion }\end{array}$ & $\begin{array}{c}2 \\
\text { Attention }\end{array}$ & $\begin{array}{c}3 \\
\text { Professional } \\
\text { Efficiency }\end{array}$ \\
\hline 1 & $0,0 \%$ & $12,5 \%$ & $87,5 \%$ \\
\hline 2 & $12,5 \%$ & $62,5 \%$ & $25,0 \%$ \\
\hline 3 & $0,0 \%$ & $25,0 \%$ & $75,0 \%$ \\
\hline 4 & $0,0 \%$ & $37,5 \%$ & $62,5 \%$ \\
\hline 5 & $0,0 \%$ & $37,5 \%$ & $62,5 \%$ \\
\hline 6 & $12,5 \%$ & $25,0 \%$ & $62,5 \%$ \\
\hline 7 & $25,0 \%$ & $25,0 \%$ & $50,0 \%$ \\
\hline 8 & $0,0 \%$ & $12,5 \%$ & $87,5 \%$ \\
\hline
\end{tabular}

\section{Discussion}

In agreement with data found in the study, Cooper and colaborators ${ }^{2}$ have shown a direct relationship between occupational stress and quality of life.

Regarding to civil aviation professionals, it is still a bland approach of research material about the subject. However, we show interest in this demand with high degree of collection efficiency associated with the speed of work processes involved in their activity, that generate and claim your burdens such as chronic pain, dissatisfaction with the activity, irregular sleep, drug addiction, depression, and others similar to what already happens to professionals in health area ${ }^{5}$.

In the sample, it was observed that among the areas assessed by WHOQOL-BREF, the environment had the lowest score reflecting directly on the quality of life assessed, and in particular regarding the lack of interest in maintaining and/or continue their academic improvement. Nevertheless, there was also that the activity itself, held by the sample has no negative impact on it, but when coupled with the student activity, shows signs of emotional overload culminating in discomfort, stress, lack of interest
$29.60 \%$, and $6.12 \%$ of the sample in condition of "Professional Exhaustion".

Whereas this group of professionals is being charged in their professional development, every day more, because of the events that are yet to come in Brazil as World Cup 2014 and Olympics in 2016, and that the sample studied had a relatively short time of activity in the company, different levels of commitment can be generated for individuals, organizations and society and promoting transformation of emergency in the workplace and organizational formats requiring a weak link in the individual-organization ${ }^{13}$.

Associated with this clue, we know that physical inactivity is a major risk factor for health according to data presented by the World Health Organization. Physical inactivity, as secondary risk factor (noncausal), has been studied scientifically since the early $50 \mathrm{~s}$, from the pioneering studies by Morris et $\mathrm{al}^{12,11}$ with groups of English workers of public enterprises, which have linked low levels of physical activity at work and mortality from cardiovascular disease, specifically heart attack and stroke. According to the IPAQ questionnaire, $25 \%$ of the sample was considered sedentary which in itself is already an aggravating factor for the quality of life and dilution the factors generating the Burnout Syndrome. However, the goal was not to classify physical activities according to their metabolic equivalents and intensity as the Compendium of Physical Activities (CAF), but really identify whether the more sedentary lifestyle could be an aggravating factor for the spread of Burnout. But despite the risks of the prominent lack of physical activity on most of the sample, it did not show indication of relevance to the symptoms of Burnout.

Organizational Climate results highlight the need for special attention with regard to identification and correction of factors that may lead to change careers, since these data influence the behavior and motivation of employees. Considering the question two, which talks about the importance and meaning of their work, $62.5 \%$ of the sample up to three episodes per week, denominated "Attention" condition, and $12.5 \%$ reported more than three episodes per week, framing it in a profile of "Professional Exhaustion". Associated with these results, questions 4 and 5 which respectively deal about "feeling tired when get up to face another day of work", $38 \%$ of the sample reported up to three episodes per week, and work and study is a great effort, where it obtained the same score, leads us to reflect about it. Observing the inquisitions held in the 
sample, and taking into account their short-service activity, was identified that a total percentage of $64.37 \%$ is in the condition of "Professional Efficiency" and $29.60 \%$ framed in a condition of "Attention", and 6.12\% included in the condition "Professional Exhaustion" demonstrating a propensity to moderate risk factors for development of burnout syndrome.

A better understanding of the organizational climate can contribute to improving the quality of human life at work, to optimize the performance of enterprise and to clarify the relationship between this behavior and other organizational variables ${ }^{9}$. Maslach and Jackson ${ }^{10}$ say that the Burnout Syndrome is primarily an emotional response, and site factors of personality, work and institutional, as conditions and antecedents of the syndrome. On the other hand, Tamayo ${ }^{14}$ points out that harmonious interpersonal relationships act as a source of social support and produce beneficial health effects, making individuals more effectively deal with occupational stress.

Given the above, and in order to maintain work activities and worker health, preventive interventions in the management processes of the environment and organization work with its own tools and regularly measured, in order to inhibit the risk agents are needed. Also, a program quality of life is relevant that focuses not only on workers' health in order to prevent disease, but more broadly where the health company in the fields physical, mental, social, academic, and organizational are taken into consideration.

Finally, we note that burnout syndrome is already included in the List of Work Related Diseases from the Brazilian Ministry of Health ${ }^{8}$. These data suggest a detailed investigation of the presence of Burnout Syndrome among airline employers.

\section{Conclusion}

In conclusion, the study found a low quality of life, especially in the environmental category, sedentary people and a large proportion of employees in this Brazilian airline with negative scores on the Organizational Climate.

\section{References}

[1] Amorim, C.; Turbay, J. Qualidade de vida no trabalho e síndrome de burnout. Anais do VII Encontro Regional Sul da ABRAPSO. Curitiba, 18-20 de setembro, p. 70, 1998.

[2] Cooper, C. et. al. Ocupational stress indicator: test souces of pressure in job. Austin: Windsor, 1988.

[3] Dejours, C. A loucura do trabalho. São Paulo: Oboré, 1994.

[4] Fleck, M. P. A.; Louzada, S.; Xavier, M.; Chachamovich, E.; Vieira, G.; Santos, L.; et. al. Aplicação da versão em português do instrumento abreviado de avaliação da qualidade de vida “Whoqol-Bref”. Rev. Saúde Pública. 2000; 34(2): 17883.

[5] Franco, G. P.; Barros, A. L. B. L.; Nogueira-Martins, L. A.; Qualidade de vida e sintomas depressivos em residentes de enfermagem. Rev. Latino-Americana de Enfermagem. 2005; 13(2): $139-44$.

[6] Guidelines for Data Processing and Analysis of the International Physical Activity Questionnaire (IPAQ) - Short and Long Forms, November 2005. htpp:// www.ipaq.ki.se/scoring.pdf//. Acesso em jul 2010.

[7] Kanaane, R. Comportamento humano nas organizações: o homem rumo ao Século XXI. São Paulo: Atlas, 1994.

[8] Lista de Doenças Relacionadas ao Trabalho, http://portal.saude.gov.br/portal/arquivos/pdf/lista_doencas_re lacionadas trabalho.pdf//Acesso em julho 2011.

[9] Martins, M. C. F., et al. Construção e validação de uma escala de medida de clima organizacional. Revista Psicologia Organizações e Trabalho. Florianopolis, v.4, n.1, p. 37-60, jan. 2004

[10]Maslach, C. P.; Jackson, S. E. The measurement of experienced burnout. Journal of Occupational Behavior, v. 2, p. 99-113, 1981.

[11] Morris, J. N. Coronary heart disease in different occupations. Lancet, $\mathrm{n}^{\circ}$ 2, p. 1053-1057, 1953b.

[12] Morris, J. N.; Heady, J. A.; Raffle, P. A. B.; Roberts, C. G.; Parks, J. W. Coronary heart disease an physical activity of work. Lancet, $n^{\circ} 2$, p. 1111-1120, 1953a.

[13] Mowday, R. T.; Porter, L. W. \& Steers, R. M. Employeeorganization linkages. New York, Academic Press, 1982.

[14] Tamayo, A. (orgs.). Cultura e saúde nas organizações. Porto Alegre: Artmed, 2004. 